\title{
Daily clenching exercise enhances the occlusal contact
}

Miwako Uchida (Divition of Orofacial Functions and Orthodontics, Kyushu Dental College)

This study was designed to investigate the effect of muscle exercise on various occlusal parameters such as occlusal contact area and occlusal contact pressure. The study subjects were healthy adult volunteers, who were divided into the exercise group and control group. Subjects in the exercise group performed isometric clenching against a soft bite block over 8 weeks. Occlusal contact area and pressure were recorded using a dental prescale film and analyzed by Occluzer. Recording of occlusal parameters was repeated three times and repeated over five days in the control group and every week for 8 weeks in the exercise group. The occlusal contact areas increased, respectively following 8-week exercise. The exercise did not significantly change the balance of right and left occlusal contact area, but significantly increased the balance of the anterior-posterior occlusal contact area. Our results indicate that isometric muscle exercise for 8 weeks increases occlusal contact area and advances forward the balance of occlusal contact area.

\section{The lip sealing function correlates with increased facial height}

䅏田 隆資（九歯大·顎口腔機能矯正学） 本研究では下顎骨の時計回転による顔面高の増加と口唇閉鎖機能との関係について検討した。被験者は安静時にお ける口唇閉鎖時（EMLC）と離開時（EMLA）の下唇の筋活動をもとに，無力性口唇を有する者（IL 群：8名）と有 さない者（CL 群：9名）に分類された成人 17 名である. 個々の被験者で上下顎切歯間距離を $0 \mathrm{~mm}$ から $2 \mathrm{~mm}$ ごと に $6 \mathrm{~mm}$ まで増加した 4 種類のオクルーザルスプリントをロ腔内に装着し下唇の筋活動の記録を行った。 EMLC， EMLC-EMLA，（EMLC-EMLA）/EMLC を下唇の筋活動の指標とした．結果から，下顎の時計方向への回転による 顔面高の増加が口唇閉鎖機能に対して有意な影響があること，特に CL 群では口唇閉鎖機能不全を引き起こす顔面高 の増加に閾值が存在することが示された.

\section{The lip saling function correlates with increased facial height}

Takashi Nokita (Divition of Orofacial Functions and Orthodontics, Kyushu Dental College)

In this study, the lip sealing function was investigated in individuals with increased anterior facial height by mandibular clockwise rotation. Seven-teen adult volunteers with normal incisor relationship and without severe anterior crowding were divided into 9 competent and 8 incompetent lip subjects based on EMG activities of lower lip at rest with the lips in contact and apart. The inter-incisal distance was increased evey $2.0 \mathrm{~mm}$ to $6.0 \mathrm{~mm}$ with occlusal splint, while EMG activities of the lower lip were recorded. The results suggest that increased facial height by clockwise rotation of the mandible has significant effect on the lip sealing function in the competent lip subjects, and there seems to be threshold inducing lip incompetence according to the increased facial height.

\section{EMD (Enamel matrix derivative) はマウスの骨随培養において, RANKL 産生を介して破骨細胞様細胞形成 を促進させる}

大塚 登志 (九歯大·顎口腔機能矯正学)

我々は，in vitro マウス骨䯣培養系を用いて，EMDの破骨細胞形成への影響とその作用メカ二ズムを調べた，高 速液体クロマトグラフィー（HPLC）により，EMDを精製し，マウス骨䯣細胞とともに 8 日間培養した。 TRAP染色 を行い 3 核以上の TRAP 陽性多核巨細胞を破骨細胞としてカウントし，骨芽細胞様細胞からの receptor activator of $\mathrm{NF}-\kappa \mathrm{B}$ ligand (RANKL) 発現を免疫ブロッティング法で確認した。 その結果 $\mathrm{EMD}$ を $0.1 \%(\mathrm{vol} / \mathrm{vol})$ トリフ ルオロ酢酸で溶解し，HPLCを用いて精製したよころ，2つの大きなピークが得られたそのうち，fraction \#21-25 の分画が，マウス骨髄培養系実験において破骨細胞の形成を誘導した。さらに，マウス骨䯣培養系実験におけ 